\title{
The Mediating Effect of Agility: IT's Impact on Firm Performance among U.S. Manufacturing Firms
}

\author{
Sharon E. DeGroote* and Thomas G. Marx
}

College of Management, Lawrence Technological University, 21000 West 10 Mile Road, Southfield, MI 48075 United States

\begin{abstract}
This study investigates the mechanism through which IT affects performance using mediation analysis to determine if agility, the ability to sense and respond to changes in the market, explains "how" or "why" IT affects performance. The results of the mediation analysis are based on data collected from survey responses from 193 U.S. manufacturing firms. Agility as a mediator was investigated using three testing methods: causal steps strategy, product of coefficients, and bootstrapping. Causal steps strategy tested the direct effects using regression analysis, the product of coefficients tested the statistical significance of the mediation effects assuming the coefficients were normally distributed, and bootstrapping tested the significance of the mediation effects without assuming they were normally distributed by creating a distribution of the product of coefficients. The mediation effect using all three tests was demonstrated, providing a robust confirmation that agility mediates the impacts of IT on firm performance.
\end{abstract}

Keywords: Agility; Information technology; Mediating variable; Firm performance

\section{Introduction}

Global competition and the accelerating pace of technological and market changes make the ability to sense and respond to market changes critical to business [1-3], and especially important for firms that rely on extended, often global, supply chains to bring products to market $[4,5]$. The ability to sense and respond is captured in the concept of 'agility' $[5,6]$. Agile firms are firms that adapt to and perform well in today's rapidly changing markets and technological environments [7-9].

Firms use many tools to help them sense and respond to market changes ahead of rivals, including market and consumer research conducted in-house or purchased from consulting firms; demographics analysis; trends analysis; scenario building; and economic forecasting models among others. Recent advances in information technologies also have the potential to significantly increase firm agility $[3,10]$. However, there are few empirical studies showing that IT enhances agility or, more importantly, that agility is the mechanism through which IT affects firm performance. This study focuses on identifying the mechanisms through which IT affects firm performance, which is essential to effective IT investment, design, and implementation.

In previous empirical research, we found that IT enhanced both supply chain agility $(\beta=0.725)$ and firm performance $(\beta=0.392)$ [11]. Specifically, the study found that IT enhanced both the sense ( $\beta=0.633)$ and respond $(\beta=0.786)$ dimensions of supply chain agility, and improved firms' financial performance measured by sales, market share, and profitability $(\beta=0.633)$, and operational performance measured by speed to market and customer satisfaction $(\beta=0.440)$. All regression coefficients had $\mathrm{p}$ values less than .01 .

These findings show that IT affects both agility and performance, but do not demonstrate how IT affects performance. Mediation analysis is used when the researcher is interested in "how" or "why" one variable affects another in order to increase the understanding of the (black box) relationships among variables [12]. This is valuable to formulating actions to enhance the relationships in ways that contribute to the achievement of ultimate goals. Mediation analysis is used in this study to determine if agility, the ability to sense and respond to changes in the market, explains "how" or "why" IT affects firm performance.

\section{Mediation model}

The mediation model was developed to test if agility is the operational mechanism through which IT affects firm performance (Figure 1). It is based on the three constructs: IT Use, Agility, and Firm Performance. IT is the independent variable, firm performance the dependent variable, and agility, the mediating variable. The components used to measure each construct in Figure 1 is shown in Table 1.

Causal steps strategy, product of coefficients, and bootstrapping methodologies are used to test whether agility mediates IT's impact on firm performance. The direct effects of IT on firm performance are first tested using regression analysis following the causal steps strategy [13].

Three regressions are run:

(1) Firm performance on IT

(2) The mediating variable agility on IT

(3) Firm performance on IT and the mediating variable agility.

The hypothesized mediating role of agility is confirmed if all coefficients of the three regressions are statistically significant at

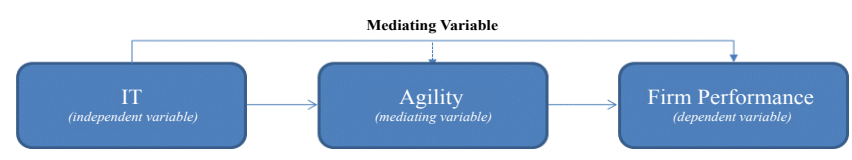

Figure 1: Mediation Model.

*Corresponding author: Sharon E .DeGroote*, College of Management, Lawrence Technological University, 21000 West 10 Mile Road, Southfield, MI 48075 United States, Tel: +49-151-2051-2244; E-mail: s_degroote@yahoo.com

Received January 15, 2014; Accepted February 17, 2014; Published February 22, 2014

Citation: DeGroote SE, Marx TG (2014) The Mediating Effect of Agility: IT's Impact on Firm Performance among U.S. Manufacturing Firms. Ind Eng Manage 3: 123. doi: 10.4172/2169-0316.1000123

Copyright: (C) 2014 DeGroote SE, et al. This is an open-access article distributed under the terms of the Creative Commons Attribution License, which permits unrestricted use, distribution, and reproduction in any medium, provided the original author and source are credited. 


\begin{tabular}{|c|c|c|}
\hline Construct & Operationalized & Scale \\
\hline IT Use & $\begin{array}{l}\text { IT use to sense market changes in } \\
\text { customer demand } \\
\text { IT use to sense market changes in } \\
\text { competitor actions } \\
\text { IT use to sense market changes in } \\
\text { technology trends } \\
\text { IT use to respond by developing } \\
\text { coordinated plan with supply chain } \\
\text { IT use to respond by executing a } \\
\text { coordinated plan with supply chain }\end{array}$ & $\begin{array}{l}1 \text { Not at all } \\
2 \text { Small extent } \\
3 \text { Moderate extent } \\
4 \text { Large extent } \\
5 \text { Very large extent }\end{array}$ \\
\hline Agility & $\begin{array}{l}\text { Information quality in terms of adequacy } \\
\text { Information quality in terms of accuracy } \\
\text { Information quality in terms of accessibility } \\
\text { Information quality in terms of timeliness } \\
\text { Develop coordinated plan with supply } \\
\text { chain in terms of timeliness } \\
\text { Develop coordinated plan with supply } \\
\text { chain in terms of cost } \\
\text { Develop coordinated plan in terms of } \\
\text { quality/effectiveness } \\
\text { Execute coordinated plan with supply } \\
\text { chain in terms of timeliness } \\
\text { Execute coordinated plan with supply } \\
\text { chain in terms of cost } \\
\text { Execute coordinated plan with supply } \\
\text { chain in terms of quality/effectiveness }\end{array}$ & $\begin{array}{l} \\
1 \text { Not at all } \\
2 \text { Small extent } \\
3 \text { Moderate extent } \\
4 \text { Large extent } \\
5 \text { Very large extent }\end{array}$ \\
\hline $\begin{array}{c}\text { Firm } \\
\text { Performance }\end{array}$ & $\begin{array}{l}\text { Sales } \\
\text { Market share } \\
\text { Profitability } \\
\text { Speed to market } \\
\text { Customer service }\end{array}$ & $\begin{array}{l}1 \text { Very negative } \\
2 \text { Somewhat } \\
\text { negative } \\
3 \text { No effect } \\
4 \text { Somewhat positive } \\
5 \text { Very positive }\end{array}$ \\
\hline
\end{tabular}

Note: Constructs measured along a 5-point Likert scale (1=low, 5=high)

Table 1: Components of IT, Agility, and Firm Performance Constructs.

the $95 \%$ level; and if the hypothesized mediator, agility, reduces the effect of IT on firm performance. This is determined by comparing the coefficients of regression for IT in the first and third regression equations. Mediation is demonstrated if the coefficient of regression for IT is reduced in the third equation where the mediation variable, agility, is introduced.

However, even if all three regressions are statistically significant at the $95 \%$ level, and the IT coefficient of regression is reduced when agility is introduced into the equation, the statistical significance of the mediation effect is not known. Mediation is strongly suggested but it is not statistically tested. The product of coefficients test is therefore used to determine the significance of the mediating effect of agility. The mediation effect is the product of the two indirect effects in Figure 1. It is the product of the impact of IT (independent variable) on agility (mediating variable) and the impact of agility (mediating variable) on firm performance (dependent variable). Dividing this mediating effect by its standard error yields a $\mathrm{Z}$ score for the mediation effect that can be compared with a standard normal distribution. Thus, if the $\mathrm{Z}$ score is greater than 1.96 , the mediation effect is statistically significant at the .05 level $[14,15]$.

The product of coefficients test, however, is limited by its assumption that the product of the indirect effects is distributed normally. Since the distribution of the product of two variables is unlikely to be distributed normally despite a large sample size, bootstrapping is used as the principal test of the significance of the mediation effect. Bootstrapping is a nonparametric test that does not require the indirect effect to be distributed normally. Bootstrapping entails running 5,000 samples of the original data to generate an empirical distribution of the indirect effects [16]. It then calculates the regression coefficients, standard errors, and percentage confidence intervals (95\% level) for this distribution. The indirect effect is statistically significant if zero is not within the range of the confidence interval. Confirmation of the mediating relationship by all three tests, would provide confidence that agility mediates IT's impact on firm performance.

\section{Results of the mediation analysis}

The results of the mediation analysis are based on responses to a survey mailed to 1,445 individuals with supply chain responsibilities at large U.S. manufacturing firms. A total of 193 usable responses were received. Table 2 shows the number of responses by the respondent's position, organizational, and geographical scope of responsibilities in the firm, and by the size of the firm measured by global sales.

Over $85 \%$ of the respondents held positions of Director or higher within their firms; $70 \%$ had global responsibilities; over half had corporate-wide responsibilities; and a third had responsibilities for multiple business units within their firms. Nearly two-thirds of the firms had global sales in excess of $\$ 2$ billion; one quarter had sales greater than $\$ 10$ billion.

The survey instrument was tested for the reliability and validity of the three constructs: IT Use (5 items), Agility (10 items), and Firm Performance (5 items) using Confirmatory Factor Analysis and Cronbach's alpha test. The results of reliability and validity testing indicate that all three constructs have both high reliability and high validity (Table 3 ).

The two-item sub construct of operational measures (FP6) in the Firm Performance (FP1) construct had Cronbach's alpha of 0.671 , which represents acceptable reliability. Since Cronbach's alpha can underestimate reliability with scales of five items or less, the SpearmanBrown prophesy formula may be used to adjust for alpha values [18].

\begin{tabular}{|c|c|c|}
\hline & $\mathbf{N}$ & $\%$ \\
\hline Sample & 193 & 100 \\
\hline \multicolumn{3}{|l|}{ Title/Position } \\
\hline Manager & 15 & $7.8^{*}$ \\
\hline Senior Manager & 12 & 6.2 \\
\hline Director & 116 & 60.1 \\
\hline Vice President & 32 & 16.5 \\
\hline Senior Vice President & 6 & 3.1 \\
\hline $\mathrm{ClO}$ & 1 & 0.5 \\
\hline General Manager & 5 & 2.6 \\
\hline Other & 6 & 3.1 \\
\hline \multicolumn{3}{|l|}{ Geographic Area of Responsibility } \\
\hline Global & 136 & $70.5^{*}$ \\
\hline National & 34 & 17.6 \\
\hline Regional & 23 & 11.9 \\
\hline \multicolumn{3}{|l|}{ Area of Firm Supported } \\
\hline Corporation (corporate-wide) & 107 & $55.4^{*}$ \\
\hline Multiple Business Units / Segments & 64 & 33.2 \\
\hline Single Business Unit / Segment & 22 & 11.4 \\
\hline \multicolumn{3}{|l|}{ Global Sales } \\
\hline$\$ 0-\$ 700$ million & 32 & $16.6^{*}$ \\
\hline$>\$ 700$ million to $\$ 1$ billion & 16 & 8.3 \\
\hline$>\$ 1$ billion to $\$ 1.5$ billion & 12 & 6.2 \\
\hline$>\$ 1.5$ billion to $\$ 2$ billion & 9 & 4.7 \\
\hline$>\$ 2$ billion to $\$ 3$ billion & 26 & 13.5 \\
\hline$>\$ 3$ billion to $\$ 5$ billion & 29 & 15.0 \\
\hline$>\$ 5$ billion to $\$ 10$ billion & 20 & 10.4 \\
\hline Greater than $\$ 10$ billion & 49 & 25.4 \\
\hline
\end{tabular}

Note: ${ }^{*} p<.05$ Chi-square test

Table 2: Respondent and Firm Characteristics. 


\begin{tabular}{|c|c|c|c|c|c|c|}
\hline Construct & Sub Contruct & Item & Mean & SD & $\alpha$ & Factor \\
\hline $\begin{array}{l}\text { IT Use } \\
\text { IT1 }\end{array}$ & $\begin{array}{l}\text { IT2 } \\
\text { IT6 }\end{array}$ & $\begin{array}{l}\text { IT3 } \\
\text { IT4 } \\
\text { IT5 } \\
\\
\text { IT7 } \\
\text { IT8 }\end{array}$ & $\begin{array}{l}2.768 \\
2.751 \\
3.093 \\
2.518 \\
\\
2.643 \\
2.793 \\
2.679 \\
2.907\end{array}$ & $\begin{array}{l}0.787 \\
0.869 \\
1.095 \\
0.969 \\
1.032 \\
0.944 \\
0.963 \\
1.037\end{array}$ & $\begin{array}{l}0.830 \\
0.793 \\
\\
0.784\end{array}$ & $\begin{array}{l}0.765 \\
0.659 \\
0.807 \\
0.809 \\
0.798 \\
0.899 \\
0.872\end{array}$ \\
\hline $\begin{array}{r}\text { Agility } \\
\text { AG1 }\end{array}$ & $\begin{array}{l}\text { AG2 } \\
\text { AG7 }\end{array}$ & $\begin{array}{c}\text { AG3 } \\
\text { AG4 } \\
\text { AG5 } \\
\text { AG6 } \\
\text { AG8 } \\
\text { AG9 } \\
\text { AG10 } \\
\text { AG11 } \\
\text { AG12 } \\
\text { AG13 }\end{array}$ & $\begin{array}{l}2.964 \\
3.168 \\
2.990 \\
3.124 \\
3.275 \\
3.285 \\
2.827 \\
2.829 \\
2.668 \\
2.814 \\
2.969 \\
2.777 \\
2.907\end{array}$ & $\begin{array}{l}0.822 \\
0.892 \\
0.968 \\
0.955 \\
1.022 \\
0.993 \\
0.916 \\
1.029 \\
1.007 \\
0.966 \\
1.045 \\
1.044 \\
1.032\end{array}$ & $\begin{array}{l}0.945 \\
0.927 \\
0.952\end{array}$ & $\begin{array}{l}0.786 \\
0.888 \\
0.881 \\
0.824 \\
0.832 \\
0.867 \\
0.816 \\
0.821 \\
0.897 \\
0.951 \\
0.840 \\
0.905\end{array}$ \\
\hline $\begin{array}{l}\text { Firm Performance } \\
\text { FP1 }\end{array}$ & $\begin{array}{l}\text { FP2 } \\
\text { FP6 }\end{array}$ & $\begin{array}{l}\text { FP3 } \\
\text { FP4 } \\
\text { FP5 } \\
\text { FP7 } \\
\text { FP8 }\end{array}$ & $\begin{array}{l}3.665 \\
3.649 \\
3.710 \\
3.523 \\
3.715 \\
3.689 \\
3.580 \\
3.798\end{array}$ & $\begin{array}{l}0.594 \\
0.619 \\
0.691 \\
0.744 \\
0.727 \\
0.669 \\
0.813 \\
0.726\end{array}$ & $\begin{array}{l}0.861 \\
0.822 \\
\\
0.671\end{array}$ & $\begin{array}{l}0.885 \\
0.805 \\
0.780 \\
0.757 \\
1.085 \\
0.666 \\
0.764\end{array}$ \\
\hline
\end{tabular}

Note: Mean/SD of constructs measured along a 5-point Likert scale ( $1=$ low, $5=$ high). $N=193 . \alpha=$ Cronbach's alpha test of internal consistency. Tests of model fit for confirmatory factor analysis (CFA): $\mathrm{X} 2=299.998, \mathrm{df}=152, \mathrm{p}<.001$; RMSEA $(90 \% \mathrm{Cl})=.071(.059-.083)$; CFI $=.954$. All factor loadings are significant at $p<.05$. Refer to Table 4 for the coding of the variables used in this table

Table 3: Reliability and Validity of IT Use (IT), Agility (AG), and Firm Performance (FP) Constructs.

As such, the alpha value $(\alpha=0.671)$ for the operational measure sub construct (FP6) was adjusted to 0.803 using the Spearman-Brown prophesy formula: $\rho_{\mathrm{xx}}^{\prime \prime}=\frac{2 \rho_{\mathrm{xx}^{\prime}}}{1+\rho_{\mathrm{xx}^{\prime}}}$

The results of the mediation analysis are presented in Tables 5 and 6. Significance was determined by Type I error rates less than $p=0.05$ (two-tailed tests). Table 5 presents the results of the three regressions for the mediation analysis. As shown, a significant relationship was found between IT and firm performance, IT and agility, and between IT, agility and firm performance as $\mathrm{p}$ values were less than .05 for all three regressions. Critically, the coefficient of regression was lower for IT in the third equation $(\beta=0.229)$, than in the first equation $(\beta=0.403)$. That is, the impact of IT on firm performance was reduced when the mediation variable, agility, was introduced into the equation. This suggests that agility mediates the impact of IT on performance. However, while the significance of the mediation effect is strongly suggested, it is not statistically tested.

The final step in confirming that agility mediates IT's impact on firm performance was conducted using the nonparametric bootstrapping test [16]. Five thousand samples were run in this re-sampling procedure to estimate the empirical distribution of the indirect effects, and their statistical significance. The regression coefficients, standard errors, and the percentile confidence intervals (95\% level) were calculated for the estimated empirical distribution of indirect effects. The confidence interval, as shown in Table 6, was 0.082 to 0.266 . Since zero is not within the confidence interval, the indirect effect is statistically significant at the $95 \%$ level, confirming that IT impacts firm performance through the mediator, agility.
In summary, the mediating role of agility on IT's impact on firm performance was investigated using three testing methods. The results of the causal steps strategy suggested a mediation effect. The product of coefficients test confirmed the mediation effect, assuming a normal distribution. Finally, bootstrapping confirmed the mediation effect without assuming the product of the indirect effects is normally distributed. Confirmation of the mediation effect by all three tests provides a robust confirmation that agility mediates the impacts of IT on firm performance.

\section{Discussion and Conclusions}

This paper extends prior analyses of the impacts of IT on agility and firm performance by demonstrating that agility is the mechanism through which IT affects both financial and operating performance. These findings have important implications for firms contemplating investments in IT. To optimize these investments, firms should focus on employing IT to improve the sense and respond dimensions of agility because both of these lead directly to improved firm performance.

These findings are especially relevant to the selection of specific technologies for coordinating operations throughout the supply chain. ERP systems are widely accepted as critical technologies to coordinate supply chain activities. Future investments, either as expansions of or as alternatives to the current ERP system, can improve firm performance by enhancing supply chain agility. Specifically, IT deployments that improve the quality of information flows throughout the supply chain (improve the adequacy, accuracy, accessibility, and timeliness of information flows), and that increase the firm's ability to develop and execute coordinated plans throughout the supply chain (in terms of quality, cost, and timeliness) are expected to contribute to improved 
Citation: DeGroote SE, Marx TG (2014) The Mediating Effect of Agility: IT's Impact on Firm Performance among U.S. Manufacturing Firms. Ind Eng Manage 3: 123. doi: 10.4172/2169-0316.1000123

Page 4 of 5

financial and operating performance. This finding is essential to IT professionals concerned with how IT adds value to the firm [3].

The authors are aware of only one other empirical study, limited to the automotive industry, of the mediating role of agility on IT's impact on firm performance Vickery et al. [18].

Although the measures used for evaluating agility and firm performance were not identical to this study, Vickery et a [18]l. also found that IT impacts firm performance through the mediator agility. The findings of this study support Vickery et al. [18], and, more importantly, generalize these findings beyond a single industry.

\section{Future Research and Limitations}

The findings of this study provide new insights into IT's impact

\begin{tabular}{|c|c|c|}
\hline Code & $\begin{array}{l}\text { Composition } \\
\text { of Code }\end{array}$ & Item \\
\hline \multicolumn{3}{|c|}{ Constructs: } \\
\hline $\begin{array}{l}\text { IT Use } \\
\text { IT1 } \\
\text { IT2 } \\
\text { IT3 } \\
\text { IT4 } \\
\text { IT5 } \\
\text { IT6 } \\
\text { IT7 } \\
\text { IT8 }\end{array}$ & $\begin{array}{l}\text { Sum of IT3- } \\
\text { IT5, IT7-IT8 } \\
\text { Sum of IT3, } \\
\text { IT4, IT5 }\end{array}$ & $\begin{array}{l}\text { IT Use Construct } \\
\text { Sub Construct: Sense } \\
\text { IT use to sense market changes in customer } \\
\text { demand } \\
\text { IT use to sense market changes in competitor } \\
\text { actions } \\
\text { IT use to sense market changes in technology } \\
\text { trends } \\
\text { Sub Construct: Respond } \\
\text { IT use to respond by developing coordinated plan } \\
\text { with supply chain } \\
\text { IT use to respond by executing coordinated plan } \\
\text { with supply chain }\end{array}$ \\
\hline \multicolumn{3}{|l|}{ Agility } \\
\hline $\begin{array}{l}\text { AG1 } \\
\text { AG2 } \\
\text { AG3 } \\
\text { AG4 } \\
\text { AG5 } \\
\text { AG6 } \\
\text { AG7 } \\
\text { AG8 } \\
\text { AG9 } \\
\text { AG10 } \\
\text { AG11 } \\
\text { AG12 } \\
\text { AG13 }\end{array}$ & $\begin{array}{l}\text { Sum of AG3- } \\
\text { AG6, AG8- } \\
\text { AG13 } \\
\text { Sum of AG3, } \\
\text { AG4, AG5, } \\
\text { AG6 }\end{array}$ & $\begin{array}{l}\text { Agility Construct } \\
\text { Sub Construct: Sense } \\
\text { Information quality in terms of adequacy } \\
\text { Information quality in terms of accuracy } \\
\text { Information quality in terms of accessibility } \\
\text { Information quality in terms of timeliness } \\
\text { Sub Construct: Respond } \\
\text { Develop coordinated plan with supply chain in } \\
\text { terms of timeliness } \\
\text { Develop coordinated plan with supply chain in } \\
\text { terms of cost } \\
\text { Develop coordinated plan in terms of quality/ } \\
\text { effectiveness } \\
\text { Execute coordinated plan with supply chain in } \\
\text { terms of timeliness } \\
\text { Execute coordinated plan with supply chain in } \\
\text { terms of cost } \\
\text { Execute coordinated plan with supply chain in } \\
\text { terms of quality/effectiveness }\end{array}$ \\
\hline \multicolumn{3}{|c|}{ Firm Performance } \\
\hline $\begin{array}{l}\text { FP1 } \\
\text { FP2 } \\
\text { FP3 } \\
\text { FP4 } \\
\text { FP5 } \\
\text { FP6 } \\
\text { FP7 } \\
\text { FP8 }\end{array}$ & $\begin{array}{l}\text { Sum of FP3- } \\
\text { FP5, FP7-FP8 } \\
\text { Sum of FP3, } \\
\text { FP4, FP5 }\end{array}$ & $\begin{array}{l}\text { Firm Performance Construct } \\
\text { Sub Construct: Financial Measures } \\
\text { Sales } \\
\text { Market share } \\
\text { Profitability } \\
\text { Sub Construct: Operational Measures } \\
\text { Speed to market } \\
\text { Customer service }\end{array}$ \\
\hline
\end{tabular}

Table 4: Nomenclature of Coding for Hypotheses Testing Results.

\begin{tabular}{|c|c|c|c|c|c|c|c|}
\hline Equation & DV & IV & B & SE & $\boldsymbol{t}$ & $\boldsymbol{p}^{*}$ & $\boldsymbol{R}^{\mathbf{2}}$ (adj) \\
\hline 1 & FP1 & IT1 & 0.403 & 0.046 & 8.73 & 0.000 & $28.1 \%$ \\
2 & AG1 & IT1 & 0.725 & 0.054 & 13.34 & 0.000 & $48.0 \%$ \\
3 & FP1 & IT1 & 0.229 & 0.062 & 3.71 & 0.000 & $33.5 \%$ \\
\hline
\end{tabular}

Note: *Regression coefficient at $p<0.01$ level. IT1 = IT, AG1 = Agility, FP1 = Firm Performance

Table 5: Regression Analysis of Casual Steps Strategy.

\begin{tabular}{|c|c|c|c|c|c|c|}
\hline & \multicolumn{2}{|c|}{ Product of Coefficients } & \multicolumn{2}{c|}{ Bootstrapping } \\
\hline & $\begin{array}{c}\text { Point } \\
\text { Estimate }\end{array}$ & SE & $\mathbf{Z}$ & P-Value & $\begin{array}{c}\mathbf{9 5 \%} \text { CI } \\
\text { Lower }\end{array}$ & $\begin{array}{c}\mathbf{9 5 \%} \text { CI } \\
\text { Upper }\end{array}$ \\
\hline & \multicolumn{5}{|c|}{ Direct Effects } \\
\hline IT & 0.229 & 0.059 & 3.887 & $0.000^{*}$ & 0.113 & 0.326 \\
AG & 0.240 & 0.063 & 3.818 & $0.000^{*}$ & 0.117 & 0.363 \\
\hline & \multicolumn{7}{|c|}{ Indirect Effects } \\
\hline AG & 0.174 & 0.047 & 3.703 & $0.000^{*}$ & 0.082 & 0.266 \\
\hline
\end{tabular}

Note: 5,000 bootstrap samples. $\mathrm{Cl}=$ confidence Interval. FP = Firm Performance $\mathrm{IT}=$ Information Technology; $\mathrm{AG}=$ Agility. ${ }^{*} \mathrm{p}<.05 ; Z>1.96$. Direct effects: dependent variable $=\mathrm{FP}$ (firm performance), independent variables IT and AG (Agility)

Table 6: Analysis of Product of Coefficients and Bootstrapping.

on supply chain agility and firm performance that can serve as both a theoretical and empirical base for future research. This study also demonstrates the application of a statistical technique, mediation analysis that can be applied in future research to provide greater understanding of the causal relationships among IT, agility, other potential mediators, and firm performance. Additional insights into the effective deployment of IT could be produced by investigating the conditions under which IT deployments have their greatest impacts on the coordination of supply chain operations. For example, what specific functional areas and processes (product development, procurement, production, logistics, and service) would benefit most from the application of IT systems.

This study focused on large U.S. manufacturers, which may restrict the applicability of the findings to smaller firms, non-U.S. firms, and service providers. Almost 65 percent of the firms participating in this study had annual sales in excess of $\$ 2$ billion, and over 35 percent of the firms had annual sales in excess of $\$ 5$ billion. Since this study was limited to manufacturers, the results should be applied with caution to service firms. Finally, the study focused on U.S. firms, which although they operate globally, may not operate under market, supply chain, or technological conditions similar to foreign firms. Therefore, generalizing the results to firms outside the U.S. should also be done with caution. Consequently, extending this research to smaller firms, service firms, and non-U.S. firms are fruitful areas for future research.

\section{References}

1. Ganguly A, Nilchiani R, Farr JV (2009) Evaluating agility in corporate enterprises. Int J Prod Econ 118:410-423.

2. Overby E, Bharadwaj A, Sambamurthy V (2006) Enterprise agility and the enabling role of information technology. Eur J Inform Syst 15: 120-131.

3. Sambamurthy V, Bharadwaj A, Grover V (2003) Shaping agility through digita options: Reconceptualizing the role of information technology in contemporary firms. MIS Quarterly 27: 237-263.

4. Christopher M (2000) The agile supply chain: Competing in volatile markets Ind Market Manag 29: 37-44.

5. van Hoek RI, Harrison A, Christopher M (2001) Measuring agile capabilities in the supply chain. Int J Oper Prod Man 21: 126-147.

6. Preiss K, Goldman SL, Nagel RN (1996) Cooperate to compete: Building agile business relationships. John Wiley \& Sons, New York: Van Nostrand Reinhold.

7. Prahalad CK, Hamel G (1990) The core competence of the corporation Harvard Business Review, May-June: 79-91.

8. Teece DJ, Pisano G, Shuen A (1997) Dynamic capabilities and strategic management. Strategic Manage J 18: 509-533.

9. Yusuf YY, Gunasekaran A, Adeleye EO, Sivayoganathan K (2004) Agile supply chain capabilities: Determinants of competitive objectives. Eur J Oper Res 159: 379-392. 
Citation: DeGroote SE, Marx TG (2014) The Mediating Effect of Agility: IT's Impact on Firm Performance among U.S. Manufacturing Firms. Ind Eng Manage 3: 123. doi: 10.4172/2169-0316.1000123

10. Oosterhout V, Waarts M, Eric, Hillegersberg VJ (2006) Change factors requiring agility and implications for IT. Eur J Inform Syst 15: 132-145.

11. DeGroote S, Marx T (2013)The impact of IT on supply chain agility and firm performance: An empirical investigation. Int J Inform Manage 33: 909-916.

12. Frazier PA, Tix AP, Barron KE (2004) Testing moderator and mediator effects in counseling psychology research. J Couns Psychol 51: 115-134.

13. Baron RM, Kenny DA (1986) The moderator-mediator variable distinction in social psychological research: Conceptual, strategic, and statistical considerations. J Pers Soc Psychol 51:1173-1182.

14. MacKinnon DP (2008) An introduction to statistical mediation analysis. New York: Routledge.
15. MacKinnon DP, Cox MC (2012) Commentary on "Mediation analysis and categorical variables: The final frontier" by Dawn lacobucci. J Consum Psychol22: 600-602.

16. Preacher KJ, Hayes AF (2008) Assymptotic and resampling strategies for assessing and comparing indirect effects in multiple mediator models. Journal of Behavior Research Method 40: 879-891.

17. Vickery SK, Droge C, Setia P, Sambamurthy V (2010) Supply chain information technologies and organisational initiatives: complementary versus independent effects on agility and firm performance. Int J Prod Res 48: 7025-7042.

18. Charter RA (2003) A breakdown of reliability coefficients by test type and reliability method, and the clinical implications of low reliability. J Gen Psychol 130: $290-304$ 